\title{
Human Resource Outsourcing: A Competitive Strategy
}

\author{
Effulgence \\ Vol. 17, No. 1 \\ January - June 2019 \\ Rukmini Devi Institute of Advanced Studies \\ E-mail : effulgence@rdias.ac.in, Website : www.rdias.ac.in \\ http://effulgence.rdias.ac.in/user/default.aspx \\ https://dx.doi.org/10.33601/effulgence.rdias/v17/i1/2019/46-56
}

\section{Dr. Himani Sharma ${ }^{1} \unrhd \Delta$ \\ Ms. Seema}

\section{Abstract}

HR outsourcing has become a vital part for any modern organization. No doubt, HR outsourcing is beneficial for an organization but there are some challenges when a company goes for outsourcing its HR functions. The objective of present paper is to study HR managers' perception about benefits and challenges when the company decides to opt HR outsourcing and to find out important benefits and challenges of outsourcing the HR functions. Data has been collected from HR managers who are working in corporate sector. The same is analyzed with the help of mean rank, standard deviation and one way Anova. Findings of the paper reveal that outsourcing the HR functions is advantageous for the organizations.

Keywords: Human Resource, Outsourcing, Human Resource Management, Organizational benefits, Organizational challenges.

\section{INTRODUCTION}

$\mathrm{H}^{\mathrm{r}}$ $\mathrm{R}$ outsourcing is the process of transferring the whole or complete part of an organization's HR function to service provider (Adler, 2003; Pelham, 2002). HR outsourcing has been popular since the early 1990s in Western Europe and in the US, where organizations outsource almost 90 percent of their HR functions to external providers (Cook, 1999; Cook, 2005).HR outsourcing is defined as "the purchase of value creating services from external vendors that could have been performed in-house" (Gilley \& Rasheed,
2000). Simmonds and Gibson (2008) define Human Resource Outsourcing as "specific clearly defined transfer of activity to external company". HRM outsourcing means "having a third-party service provider or vendor furnish, on an ongoing basis, the administration of an HRM activity that would normally be performed in- house" (Cook, 1999). Gallagher (2000) pointed out some significant reasons for choosing HR outsourcing like reduction in expenses, better quality of services and increment in employee`s knowledge and skill. HR outsourcing can provide a help to an organization to transfer their non-core activities to some external service provider who can perform task so that they can 
concentrate on main goal (Stasiulyte, 2011). HR outsourcing can help an organization to save cost, time, and resources; moreover organization will be free of complications in maintaining internal HR department (Mahmud et al., 2012).To take the advantages of competitive environment HR outsourcing can play a significant role.(Jirawuttinunt, 2015). Instead of investing in people and technology an organization can play more strategic and proactive role with the help of HR outsourcing. (King, 2007, Lau and Zhang, 2006).

\section{LITERATURE REVIEW}

This section is devoted to review the relevant literature available in the field of HR outsourcing.

\section{Benefits of HR outsourcing}

The most important reason behind using HR outsourcing is to take advantage of specialized skills of experts (Quinn et. al. 1990). (Klaas et al., 1998; Laabs, 1993; Lever, 1997, Elmuti, 2003 and Jirawuttinunt, 2015) researched that most of the organizations outsource their HR functions to reduce cost, improve efficiency and effectiveness of their employees, improve the quality of the product, increase reliability, to enter in the foreign markets, concentrate on core competencies, to get expert skills and knowledge for new operations and to make use of managerial resources. Galanakiand Papelexandri (2007) found majority of the companies outsource their HR functions to cut cost by transfer of routine and repetitive services to outside vendor instead of keeping them in-house. HR outsourcing help in improving productivity, speeding up developing new business applications, accessing new technologies and skills and enhance the service value of the organization (Buller and Mcevoy, 2012 and Seth and Sethi, 2011). Organizations can spare themselves from different complexities that arise due to maintenance of internal HR department (Mahmud, 2012). HR outsourcing is helpful for an organization as it improves communication within organization, provides quick feedback and resolve problems easily (Fapohunda, 2013). Outsourcing HR functions can lead to lowering cost so as to take competitive advantage. (Kaleli and David, 2014). HR outsourcing gives workforce flexibility and stability to an organization and they can focus on core activities (Berber and Ślavic, 2016).

\section{Challenges in HR Outsourcing}

Robert (2001) found majority of the organizations are scared of outsourcing their HR activities because they think that they will lose control on their internal departments and moreover they also perceive that they will be dependent on the expert's knowledge if they go for HR outsourcing. If HR outsourcing is implemented without planning it can result escalating cost, reduced capacity and productivity and sometimes it may lead to downsizing (Elmuti, 2003; Casale, 1996; Outlay and Rangana than, 2005). Smith et al. (2006) state that organizations are apprehensive to outsource their HR activities because they fear that this will increases cost. Internal employee's reactions towards HR outsourcing create problems in success of HR outsourcing (Kodwani, 2007).

HR outsourcing proves to be fruitful when it is carried out in right manner (Stasiulyte, 2011). Some of the organizations fear that they will lose confidential and sensitive information due to HR outsourcing (Fapohunda, 2013). Some issues arise due to quality provided by vendors, lack of employee`s preparation towards their jobs and lack of skills to handle HR outsourcing (Azhar, 2011).Many challenges come across during HR outsourcing like lack of trust, risk, uncertainty, poor performance of expert, complaint about internal associations etc. (Fapohunda, 2013). When HR outsourcing decisions are taken in a poor manner it gives rise to increases a variety of problems like increment in cost, brand damage, disrupted service towards organizations, loss of effective knowledge and business reputations (Kaleli and David, 2014). 


\section{OBJECTIVES AND IMPORTANCE OF THE STUDY}

Following are the objectives of the study:

1. To study the perception of HR managers regarding benefits and challenges HR outsourcing.

2. To analyse the perception of HR managers across organizational variables.

\section{RESEARCH METHODOLOGY}

Data has been collected from both primary and secondary sources. Secondary data has been collected through journals, research papers, articles and reports etc. For collecting primary data a questionnaire has been designed by the researcher to collect responses. The questionnaire is segregated in two parts. First section contains 17 statements which deal with different organizational benefits of HR outsourcing that occur when an organization opt for HR outsourcing. Second section contains 13 statements regarding different organizational challenges faced by organization when they opt for HR outsourcing. Five-point Likert scale ranging from 5: Strongly Agree, 4: Agree, 3: Neutral, 2: Disagree and 1: Strongly Disagree has been employed in the study. Data has been gathered from 92 HR managers working in service and manufacturing sector from Delhi and NCR. Those companies are selected who have outsourced their HR functions from the sample of organization. Collected data has been statistically analyzed by using descriptive statistics like frequency distribution, mean rank, standard deviation and one way ANOVA. Reliability of questionnaire has been checked through cronbachalpha. The reliability coefficients of scale comprising of organizational challenges and organizational benefits is found to be 0.703 and 0.637 respectively. Scores of both the dimensions are above 0.6. It shows that both the scales are reliable and acceptable (Cronbach, L. 1951).

\section{RESULTS}

This section deals with analysis of the statements used to know the perception of respondents regarding their views on HR outsourcing.

Table 1: Respondents' Profile

$N=92$

\begin{tabular}{|l|c|c|c|}
\hline Demographics & Frequency & Category & Percent \\
\hline Gender & Male & 66 & 71.7 \\
\cline { 2 - 4 } & Female & 26 & 28.3 \\
\hline \multirow{4}{*}{ Age (years) } & Below 35 years & 42 & 45.6 \\
\cline { 2 - 4 } & 36-45 years & 42 & 45.6 \\
\cline { 2 - 4 } & Above 45 Years & 8 & 8.8 \\
\hline Experience(years) & up to 2 years & 29 & 31.5 \\
\cline { 2 - 4 } & $2-4$ years & 45 & 48.9 \\
\cline { 2 - 4 } & 4 and above 4 years & 18 & 22.8 \\
\hline Education & Graduate & 21 & 72.8 \\
\cline { 2 - 4 } & Postgraduate & 67 & 4.4 \\
\cline { 2 - 4 } & Others & 4 & 100 \\
\hline
\end{tabular}

Source: Primary Data 
Table 1 represents the respondent's profile that shows majority of respondents are male $(71.7 \%)$. Most of respondents belong to the age group of below 35 years and $36-45$ years (45.6\%). Major part of the respondents is having an experience of 4 years and above 4 years (48.9\%) in the organization. Education wise breakup depicts that postgraduates $(72.8 \%)$ play a major part in the study.

When the respondents were asked to answer about the benefits of HR outsourcing most of the respondents said that they would like to accept HR outsourcing because it is beneficial for an organization as shown in Table 2. The findings show that 72 percent of the respondents agreed that HR outsourcing is helpful to simplify HR functions and better performance. Almost 63 percent of respondents agreed that HR outsourcing can increase the performance of the organization. A large percentage $(93 \%)$ believed that organization can out source its non core activities. Most of the respondents $(88 \%)$ of respondents assured that an organization can enjoy the benefits of HR outsourcing. Seventy-seven per cent of respondents said that HR outsourcing is required to achieve vendor expertise. Majority (73\%) of them believed that HR outsourcing can help in reduction of cost. The finding indicates that 82 percent of respondents replied that they can control their internal departments in a good manner by using HR outsourcing. A decision of outsourcing core and non-core activities can easily be made with the help of HR outsourcing. Some of the respondents (63\%) told that it provides fast, effective and cheaper services to client organization. The result shows that 87 percent of respondents agreed that different decisions regarding core activities can easily be made by using HR outsourcing. Whereas, 88 percent said that HR outsourcing can bring innovation in their product and services. A large percentage of respondents $(92 \%)$ agreed that it is helpful in taking advantage of new technology by outsourcing noncore activities. Sixty six percent of respondents told that it is helpful to reduce burden. A few number
(51\%) respondents did not agree with benefits because of lack of awareness about HR outsourcing. The findings suggests that respondents (93\%) covered under this study were agreed that HR outsourcing can be helpful in taking benefits of new advancement and technology and 89 percent of respondents agreed that it provides facility to spread risk. The results also reveal mean and standard deviation of various benefits of HR outsourcing. It is clear from the table that all benefits are accepted positively by $\mathrm{HR}$ managers as the mean score is above three and four except one statement whose mean score is 2.91. This shows HR managers are disagreeing on this and they have no future plans to out source HR activities. The standard deviation of all the statements of benefits lies between 0.7 and 1 .

The perception of HR managers towards the challenges in HR outsourcing has been studied in detail in Table 3. The results of the study show that 48.9 percent of respondents believed that HR outsourcing is the reason of conflicts between internal and external employees. Some of the respondents (38\%) assumed that the confidential information is lost by using HR outsourcing. Some of the respondent, near about 40.2 percent observed that it directly affects the motivational level of employees. Most of the respondents (29.3\%) agreed that the internal staff of employees does not support HR outsourcing. Some of the HR managers (40.2\%) stated that after introducing HR outsourcing they have become more dependent on external vendors. Almost 38 percent respondents believed that due to lack of information they were not able to introduce HR outsourcing in their organizations. Nearly 34.8 percent agreed that it is difficult task to select a best service provider. The results of the study also revealed that 44.4 percent of $\mathrm{HR}$ managers face difficulty to differentiate core or non-core functions. Some of the HR managers (45.7\%) agreed that a poor past experience directly affects the present decision to out source HR functions. Almost 45.7 percent of the respondents agreed that it requires time to make a contract with vendor party. Most of the HR managers $(46.7 \%)$ stated that because of difficulty in 
Table 2 : Benefits of Human Resource Outsourcing: Perception of HR Managers

\begin{tabular}{|c|c|c|c|c|c|c|c|c|}
\hline Benefits & $\begin{array}{l}\text { Strongly } \\
\text { Agree } \\
\text { (5) }\end{array}$ & Agree (4) & $\begin{array}{l}\text { Neutral } \\
\text { (3) }\end{array}$ & $\begin{array}{l}\text { Disagree } \\
(2)\end{array}$ & $\begin{array}{l}\text { Strongly } \\
\text { Disagree } \\
\text { (1) }\end{array}$ & Mean & $\begin{array}{l}\text { Mean } \\
\text { Rank }\end{array}$ & S.D. \\
\hline $\begin{array}{l}\text { It provides facilities to } \\
\text { focus on core activities } \\
\text { like decision making, } \\
\text { policy making and } \\
\text { strategy development } \\
\text { etc. }\end{array}$ & $\begin{array}{c}57 \\
(62 \%)\end{array}$ & $\begin{array}{c}26 \\
(28.3 \%)\end{array}$ & $\begin{array}{c}8 \\
(8.7 \%)\end{array}$ & $\begin{array}{c}1 \\
(1.1 \%)\end{array}$ & $\begin{array}{l}0 \\
0\end{array}$ & 4.51 & I & .70 \\
\hline $\begin{array}{l}\text { It provides facility to } \\
\text { spread the risk. }\end{array}$ & $\begin{array}{c}49 \\
(53.3 \%)\end{array}$ & $\begin{array}{c}36 \\
(39.1 \%)\end{array}$ & $\begin{array}{c}5 \\
(5.4 \%)\end{array}$ & $\begin{array}{c}2 \\
(2.2 \%)\end{array}$ & $\begin{array}{l}0 \\
0\end{array}$ & 4.43 & II & .70 \\
\hline $\begin{array}{l}\text { Organizations can } \\
\text { outsource non core } \\
\text { activities. }\end{array}$ & $\begin{array}{c}46 \\
(50 \%)\end{array}$ & $\begin{array}{c}39 \\
(42.4 \%)\end{array}$ & $\begin{array}{c}6 \\
(6.5 \%)\end{array}$ & $\begin{array}{c}1 \\
(1.1 \%)\end{array}$ & $\begin{array}{l}0 \\
0\end{array}$ & 4.41 & III & .66 \\
\hline $\begin{array}{l}\text { It provides an } \\
\text { opportunity to take the } \\
\text { benefits of new } \\
\text { advancement and } \\
\text { technology. }\end{array}$ & $\begin{array}{c}40 \\
(43.5 \%)\end{array}$ & $\begin{array}{c}49 \\
(53.3 \%)\end{array}$ & $\begin{array}{c}3 \\
(3.3 \%)\end{array}$ & $\begin{array}{l}0 \\
0\end{array}$ & $\begin{array}{l}0 \\
0\end{array}$ & 4.40 & IV & .55 \\
\hline $\begin{array}{l}\text { It helps an organization } \\
\text { to provide improved } \\
\text { and consistent service } \\
\text { quality. }\end{array}$ & $\begin{array}{c}47 \\
(51.1 \%)\end{array}$ & $\begin{array}{c}35 \\
(38 \%)\end{array}$ & $\begin{array}{l}7 \\
(7.6 \%)\end{array}$ & $\begin{array}{c}2 \\
(2.2 \%)\end{array}$ & $\begin{array}{c}1 \\
(1.1 \%)\end{array}$ & 4.35 & V & .80 \\
\hline $\begin{array}{l}\text { It can help to control the } \\
\text { internal departments of } \\
\text { an organization in a } \\
\text { better way. }\end{array}$ & $\begin{array}{c}42 \\
(45.7 \%)\end{array}$ & $\begin{array}{c}40 \\
(43.5 \%)\end{array}$ & $\begin{array}{c}9 \\
(9.8 \%)\end{array}$ & $\begin{array}{c}1 \\
(1.1 \%)\end{array}$ & $\begin{array}{l}0 \\
0\end{array}$ & 4.33 & VI & .69 \\
\hline $\begin{array}{l}\text { It provides flexibility to } \\
\text { make changes according } \\
\text { to technology and } \\
\text { environment. }\end{array}$ & $\begin{array}{c}43 \\
(46.7 \%)\end{array}$ & $\begin{array}{c}36 \\
(39.1 \%)\end{array}$ & $\begin{array}{c}12 \\
(13 \%)\end{array}$ & $\begin{array}{c}1 \\
(1.1 \%)\end{array}$ & $\begin{array}{l}0 \\
0\end{array}$ & 4.31 & VII & .74 \\
\hline $\begin{array}{l}\text { Organization wants to } \\
\text { enjoy the benefits of HR } \\
\text { outsourcing. }\end{array}$ & $\begin{array}{c}36 \\
(39.1 \%)\end{array}$ & $\begin{array}{c}46 \\
(50 \%)\end{array}$ & $\begin{array}{c}9 \\
(9.8 \%)\end{array}$ & $\begin{array}{c}1 \\
(1.1 \%)\end{array}$ & $\begin{array}{l}0 \\
0\end{array}$ & 4.27 & VIII & .68 \\
\hline $\begin{array}{l}\text { It helps an organization } \\
\text { to make decisions about } \\
\text { core or non-core } \\
\text { activities. }\end{array}$ & $\begin{array}{c}35 \\
(53.3 \%)\end{array}$ & $\begin{array}{c}49 \\
(38 \%)\end{array}$ & $\begin{array}{c}6 \\
(6.5 \%)\end{array}$ & $\begin{array}{c}2 \\
(2.2 \%)\end{array}$ & $\begin{array}{l}0 \\
0\end{array}$ & 4.27 & VIII & .68 \\
\hline
\end{tabular}




\begin{tabular}{|c|c|c|c|c|c|c|c|c|}
\hline $\begin{array}{l}\text { By focusing on core } \\
\text { activities an } \\
\text { organizations can bring } \\
\text { innovation in their } \\
\text { product and services. }\end{array}$ & $\begin{array}{c}35 \\
(38 \%)\end{array}$ & $\begin{array}{c}47 \\
(51.1 \%)\end{array}$ & $\begin{array}{c}7 \\
(7.6 \%)\end{array}$ & $\begin{array}{c}3 \\
(3.3 \%)\end{array}$ & $\begin{array}{l}0 \\
0\end{array}$ & 4.23 & IX & .73 \\
\hline $\begin{array}{l}\text { It provides more flexible, } \\
\text { faster, cheaper and } \\
\text { effective services to } \\
\text { client organization. }\end{array}$ & $\begin{array}{c}34 \\
(37 \%)\end{array}$ & $\begin{array}{c}48 \\
(52.2 \%)\end{array}$ & $\begin{array}{c}7 \\
(7.6 \%)\end{array}$ & $\begin{array}{c}3 \\
(3.3 \%)\end{array}$ & $\begin{array}{l}0 \\
0\end{array}$ & 4.22 & $X$ & .72 \\
\hline $\begin{array}{l}\text { It enables an } \\
\text { organization to focus on } \\
\text { strategic role. }\end{array}$ & $\begin{array}{c}37 \\
(40.2 \%)\end{array}$ & $\begin{array}{c}43 \\
(46.7 \%)\end{array}$ & $\begin{array}{c}9 \\
(9.8 \%)\end{array}$ & $\begin{array}{c}2 \\
(2.2 \%)\end{array}$ & $\begin{array}{c}1 \\
(1.1 \%)\end{array}$ & 4.22 & $X$ & .79 \\
\hline $\begin{array}{l}\text { HR outsourcing help to } \\
\text { simplify HR functions in } \\
\text { an organization. }\end{array}$ & $\begin{array}{c}34 \\
(37 \%)\end{array}$ & $\begin{array}{c}48 \\
(52.2 \%)\end{array}$ & $\begin{array}{c}6 \\
(6.5 \%)\end{array}$ & $\begin{array}{c}3 \\
(3.3 \%)\end{array}$ & $\begin{array}{c}1 \\
(1.1 \%)\end{array}$ & 4.20 & XI & .79 \\
\hline $\begin{array}{l}\text { It helps in cost reduction } \\
\text { like training, recruitment } \\
\text { cost etc. }\end{array}$ & $\begin{array}{c}33 \\
(35.9 \%)\end{array}$ & $\begin{array}{c}48 \\
(52.2 \%)\end{array}$ & $\begin{array}{c}8 \\
(8.7 \%)\end{array}$ & $\begin{array}{c}2 \\
(2.2 \%)\end{array}$ & $\begin{array}{c}1 \\
(1.1 \%)\end{array}$ & 4.19 & XII & .77 \\
\hline $\begin{array}{l}\text { Organizations perform } \\
\text { better by outsourcing } \\
\text { some of HR functions. }\end{array}$ & $\begin{array}{c}28 \\
(30.4 \%)\end{array}$ & $\begin{array}{c}53 \\
(57.6 \%)\end{array}$ & $\begin{array}{c}10 \\
(10.9 \%)\end{array}$ & $\begin{array}{c}1 \\
(1.1 \%)\end{array}$ & $\begin{array}{l}0 \\
0\end{array}$ & 4.17 & XIII & .65 \\
\hline $\begin{array}{l}\text { HR Outsourcing helps to } \\
\text { gain vendor expertise. }\end{array}$ & $\begin{array}{c}27 \\
(29.3 \%)\end{array}$ & $\begin{array}{c}52 \\
(56.5 \%)\end{array}$ & $\begin{array}{l}11 \\
(12 \%)\end{array}$ & $\begin{array}{c}2 \\
(2.2 \%)\end{array}$ & $\begin{array}{l}0 \\
0\end{array}$ & 4.13 & XIV & .69 \\
\hline $\begin{array}{l}\text { It helps an organization } \\
\text { to reduce administrative } \\
\text { and regulatory burden. }\end{array}$ & $\begin{array}{c}29 \\
(31.5 \%)\end{array}$ & $\begin{array}{c}49 \\
(53.3 \%)\end{array}$ & $\begin{array}{c}10 \\
(10.9 \%)\end{array}$ & $\begin{array}{c}3 \\
(3.3 \%)\end{array}$ & $\begin{array}{c}1 \\
(1.1 \%)\end{array}$ & 4.10 & $X V$ & .80 \\
\hline
\end{tabular}

Source: Primary Data

Table 3 : Challenges in Human Resource Outsourcing: Perception of HR Managers

\begin{tabular}{|c|c|c|c|c|c|c|c|c|}
\hline Challenges & $\begin{array}{c}\text { Strongly } \\
\text { Agree } \\
\text { (5) }\end{array}$ & $\begin{array}{l}\text { Agree } \\
(4)\end{array}$ & $\begin{array}{l}\text { Neutral } \\
\text { (3) }\end{array}$ & $\begin{array}{c}\text { Disagree } \\
\text { (2) }\end{array}$ & $\begin{array}{c}\text { Strongly } \\
\text { Disagree } \\
\text { (1) }\end{array}$ & Mean & $\begin{array}{l}\text { Mean } \\
\text { Rank }\end{array}$ & S.D. \\
\hline $\begin{array}{l}\text { Before outsourcing an } \\
\text { organization should } \\
\text { differentiate between } \\
\text { core and non core } \\
\text { activities. }\end{array}$ & $\begin{array}{c}27 \\
(29.3 \%)\end{array}$ & $\begin{array}{l}41 \\
(44.6 \%)\end{array}$ & $\begin{array}{c}13 \\
(14.1 \%)\end{array}$ & $\begin{array}{c}9 \\
(9.8 \%)\end{array}$ & $\begin{array}{c}2 \\
(2.2 \%)\end{array}$ & 3.89 & I & 1.01 \\
\hline $\begin{array}{l}\text { It is a time consuming } \\
\text { process to make contract } \\
\text { with third party. }\end{array}$ & $\begin{array}{c}25 \\
(27.2 \%)\end{array}$ & $\begin{array}{c}42 \\
(45.7 \%)\end{array}$ & $\begin{array}{c}14 \\
(15.2 \%)\end{array}$ & $\begin{array}{c}11 \\
(12 \%)\end{array}$ & $\begin{array}{l}0 \\
0\end{array}$ & 3.88 & II & .94 \\
\hline
\end{tabular}




\begin{tabular}{|c|c|c|c|c|c|c|c|c|}
\hline $\begin{array}{l}\text { It increases the rate of } \\
\text { dependence on vendors. }\end{array}$ & $\begin{array}{l}27 \\
(29.3 \%)\end{array}$ & $\begin{array}{c}37 \\
(40.2 \%)\end{array}$ & $\begin{array}{c}16 \\
(17.4 \%)\end{array}$ & $\begin{array}{c}11 \\
(12 \%)\end{array}$ & $\begin{array}{c}1 \\
(1.1 \%)\end{array}$ & 3.84 & III & 1.01 \\
\hline $\begin{array}{l}\text { There is a clash between } \\
\text { internal employees and } \\
\text { third party regarding the } \\
\text { work styles. }\end{array}$ & $\begin{array}{c}26 \\
(28.3 \%)\end{array}$ & $\begin{array}{c}38 \\
(41.3 \%)\end{array}$ & $\begin{array}{c}16 \\
(17.4 \%)\end{array}$ & $\begin{array}{c}10 \\
(10.9 \%)\end{array}$ & $\begin{array}{c}2 \\
(2.2 \%)\end{array}$ & 3.82 & IV & 1.03 \\
\hline $\begin{array}{l}\text { There is difficulty in } \\
\text { evaluating the quality of } \\
\text { the services offered by } \\
\text { different providers. }\end{array}$ & $\begin{array}{c}23 \\
(25 \%)\end{array}$ & $\begin{array}{c}40 \\
(43.5 \%)\end{array}$ & $\begin{array}{c}20 \\
(21.7 \%)\end{array}$ & $\begin{array}{c}6 \\
(6.5 \%)\end{array}$ & $\begin{array}{c}3 \\
(3.3 \%)\end{array}$ & 3.80 & V & .99 \\
\hline $\begin{array}{l}\text { Past experience in HR } \\
\text { Outsourcing can } \\
\text { influence the present } \\
\text { decision to outsource. }\end{array}$ & $\begin{array}{c}21 \\
(22.8 \%)\end{array}$ & $\begin{array}{c}42 \\
(45.7 \%)\end{array}$ & $\begin{array}{c}19 \\
(20.7 \%)\end{array}$ & $\begin{array}{c}10 \\
(10.9 \%)\end{array}$ & $\begin{array}{l}0 \\
0\end{array}$ & 3.80 & V & .91 \\
\hline $\begin{array}{l}\text { It becomes the reason for } \\
\text { loosing confidential } \\
\text { information of an } \\
\text { organization. }\end{array}$ & $\begin{array}{c}26 \\
(28.3 \%)\end{array}$ & $\begin{array}{c}35 \\
(38 \%)\end{array}$ & $\begin{array}{c}17 \\
(18.5 \%)\end{array}$ & $\begin{array}{c}12 \\
(13 \%)\end{array}$ & $\begin{array}{c}2 \\
(2.2 \%)\end{array}$ & 3.77 & VI & 1.07 \\
\hline $\begin{array}{l}\text { It increases the rate of } \\
\text { conflicts between } \\
\text { internal and external } \\
\text { employees. }\end{array}$ & $\begin{array}{c}18 \\
(19.6 \%)\end{array}$ & $\begin{array}{c}45 \\
(48.9 \%)\end{array}$ & $\begin{array}{c}17 \\
(18.5 \%)\end{array}$ & $\begin{array}{c}11 \\
(12 \%)\end{array}$ & $\begin{array}{c}1 \\
(1.1 \%)\end{array}$ & 3.73 & VII & .94 \\
\hline $\begin{array}{l}\text { It is difficult to } \\
\text { coordinate information } \\
\text { flow with service } \\
\text { provider. }\end{array}$ & $\begin{array}{c}17 \\
(18.5 \%)\end{array}$ & $\begin{array}{c}43 \\
(46.7 \%)\end{array}$ & $\begin{array}{c}18 \\
(19.6 \%)\end{array}$ & $\begin{array}{c}13 \\
(14.1 \%)\end{array}$ & $\begin{array}{c}1 \\
(1.1 \%)\end{array}$ & 3.67 & VIII & .97 \\
\hline $\begin{array}{l}\text { There is lack of } \\
\text { information regarding } \\
\text { benefits of HR } \\
\text { outsourcing to HR } \\
\text { managers. }\end{array}$ & $\begin{array}{c}23 \\
(25 \%)\end{array}$ & $\begin{array}{c}31 \\
(33.7 \%)\end{array}$ & $\begin{array}{c}21 \\
(22.81 \%)\end{array}$ & $\begin{array}{c}16 \\
(17.4 \%)\end{array}$ & $\begin{array}{c}1 \\
(1.1 \%)\end{array}$ & 3.64 & IX & 1.07 \\
\hline $\begin{array}{l}\text { It affects the motivation } \\
\text { level of internal staff and } \\
\text { employees. }\end{array}$ & $\begin{array}{c}19 \\
(20.7 \%)\end{array}$ & $\begin{array}{c}37 \\
(40.2 \%)\end{array}$ & $\begin{array}{c}21 \\
(22.8 \%)\end{array}$ & $\begin{array}{c}11 \\
(12 \%)\end{array}$ & $\begin{array}{c}4 \\
(4.3 \%)\end{array}$ & 3.60 & $X$ & 1.07 \\
\hline $\begin{array}{l}\text { It is not supported by } \\
\text { internal staff or } \\
\text { employees. }\end{array}$ & $\begin{array}{c}24 \\
(26.1 \%)\end{array}$ & $\begin{array}{c}27 \\
(29.3 \%)\end{array}$ & $\begin{array}{c}23 \\
(25 \%)\end{array}$ & $\begin{array}{c}16 \\
(17.4 \%)\end{array}$ & $\begin{array}{c}2 \\
(2.2 \%)\end{array}$ & 3.59 & XI & 1.11 \\
\hline $\begin{array}{l}\text { It becomes difficult task } \\
\text { to select best service } \\
\text { provider. }\end{array}$ & $\begin{array}{c}20 \\
(21.7 \%)\end{array}$ & $\begin{array}{c}32 \\
(34.8 \%)\end{array}$ & $\begin{array}{c}21 \\
(22.8 \%)\end{array}$ & $\begin{array}{c}14 \\
(15.26 \%)\end{array}$ & $\begin{array}{c}5 \\
(5.4 \%)\end{array}$ & 3.52 & XII & 1.15 \\
\hline
\end{tabular}

Source: Primary Data 
coordination between employees it becomes difficult to introduce HR outsourcing. Many of them (43.5\%) believed that it is a challenging task to evaluate the quality of services offered by providers. Almost 41.3 percent of HR managers said that different work styles also increases the difficulties in front of HR managers. The study also reveals mean and standard deviation of collected data. It is clear from the table that the mean score is above three in all the statements. This shows HR managers agreed that they face challenges while using HR outsourcing.
The values of all these statements of challenges have shown standard deviation is near one.

The results reveal mean and standard deviation of collected data. It is clear from the table 4 that all benefits are accepted positively by HR managers as the mean score is above four. It is pertinent to mention here that there are challenges also with respect to organization and with respect to employees when an organization goes for outsourcing.

Table 4 : Table showing mean values of organizational benefits and challenges in HRO

\begin{tabular}{|c|c|c|}
\hline Dimensions & Mean & S.D \\
\hline Organizational Benefits & 4.28 & 0.30 \\
\hline \multicolumn{3}{|c|}{ Organizational Challenges: } \\
\hline A. Organization & 3.75 & 0.47 \\
\hline B. Employees & 3.70 & 0.62 \\
\hline
\end{tabular}

Source: Primary Data

Table 5 : Experience-wise Comparison of Organizational Benefits and Challenges

\begin{tabular}{|c|c|c|c|c|c|c|}
\hline Dimensions & Experience & $\mathbf{N}$ & Mean & S.D. & $\mathbf{F}$ & Sig. \\
\hline \multirow[t]{3}{*}{ Organizational Benefits } & Up to 2 years & 29 & 4.18 & 0.35 & \multirow[t]{3}{*}{3.75} & \multirow[t]{3}{*}{$0.02^{*}$} \\
\hline & $2-4$ years & 45 & 4.36 & 0.24 & & \\
\hline & Above 4 years & 18 & 4.23 & 0.28 & & \\
\hline \multirow[t]{3}{*}{ Organizational Challenges } & Less than 2 years & 29 & 3.70 & 0.44 & \multirow[t]{3}{*}{1.98} & \multirow[t]{3}{*}{0.14} \\
\hline & $2-4$ years & 45 & 3.68 & 0.42 & & \\
\hline & Above 4 years & 18 & 3.92 & 0.48 & & \\
\hline
\end{tabular}

Source: Primary Data

${ }^{*}$ significant at $5 \%$ level

On the basis of experience in table 5, the respondents have been divided in three groups viz. the employees having an experience of less than two years, employees with two to four years of experience and employees with more than four years of experience. One way ANOVA has been applied to confirm that the variables are significant at five percent level of significance or not. $F$ value for organizational benefits is 3.75 which is significant at 5 percent level. It shows Human Resource Outsourcing is significantly accepted by managers having experience of 2-4 years. Because they have more potential to work and they can easily face competitive environment. But the mean value of organizational challenges in all the three categories is more than three. It indicates that an HR manager 
faces some problems while using HR outsourcing. F value for organizational challenges is 1.98 which is not significant at 5 percent level of significance. It indicates that it is a challenging task to introduce HR outsourcing in organization.

On the basis of education in table 6, the respondents have been divided in three categories viz. graduates, post graduates and others. One way ANOVA has been applied to confirm that the variables are significant at five percent level of significance or not.
F value for organizational benefits is 3.46 which is significant at 5 percent level. It shows Human Resource Outsourcing is significantly accepted by managers having post-graduation degree. Because they have more knowledge about their work and they can easily face competitive environment. But the mean value of organizational challenges in all the three categories is more than three. $F$ value for organizational challenges is 1.98 which is not significant at 5 percent level of significance.

Table 6 : Education wise Comparison of Organizational Benefits and Challenges

\begin{tabular}{|c|c|c|c|c|c|c|}
\hline Dimensions & Education & $\mathbf{N}$ & Mean & S.D. & F & Sig. \\
\hline \multirow[t]{3}{*}{ Organizational Benefits } & Graduation & 21 & 4.33 & 0.28 & \multirow[t]{3}{*}{3.46} & \multirow[t]{3}{*}{$0.04^{*}$} \\
\hline & Post-Graduation & 67 & 4.13 & 0.34 & & \\
\hline & Others & 4 & 4.27 & 0.07 & & \\
\hline \multirow[t]{3}{*}{ Organizational Challenges } & Graduation & 21 & 3.78 & 0.38 & \multirow[t]{3}{*}{0.89} & \multirow[t]{3}{*}{0.42} \\
\hline & Post-Graduation & 67 & 3.74 & 0.47 & & \\
\hline & Others & 4 & 3.46 & 0.29 & & \\
\hline
\end{tabular}

Table 7 shows the responses of $92 \mathrm{HR}$ manager of different age group. On the basis of age, the respondents have been divided in three age groups viz. 25-35 years, 36-45 years and above 45 years. In case of organizational benefits, results reveals that the mean value of respondents in the age group of above 45 years is higher as comparison to the respondents belonging to age group of 25-35 years,

Table 7 : Age wise Comparison of Organizational Benefits and Challenges

\begin{tabular}{|c|c|c|c|c|c|c|}
\hline Dimensions & Age & $\mathbf{N}$ & Mean & S.D. & F & Sig. \\
\hline \multirow[t]{3}{*}{ Organizational Benefits } & $25-35$ years & 42 & 4.21 & 0.35 & \multirow[t]{3}{*}{3.58} & \multirow[t]{3}{*}{$0.03^{*}$} \\
\hline & $35-45$ years & 42 & 4.21 & 0.24 & & \\
\hline & Above 45 years & 8 & 4.49 & 0.07 & & \\
\hline \multirow[t]{3}{*}{ Organizational Challenges } & $25-35$ years & 48 & 3.70 & 0.47 & \multirow[t]{3}{*}{0.34} & \multirow[t]{3}{*}{0.70} \\
\hline & $35-45$ years & 36 & 3.76 & 0.39 & & \\
\hline & Above 45 years & 8 & 3.82 & 0.54 & & \\
\hline
\end{tabular}


35-45 years. One way ANOVA has been applied to confirm that the variables are significant at five percent level of significance or not. $F$ value for organizational benefits is 3.58 which is significant at 5 percent level. But the mean value of organizational challenges in all the three categories is more than three. It indicates that HR managers of different age groups face some problems regarding outsourcing of HR functions. F value for organizational challenges is 0.34 which is not significant at 5 percent level of significance. It indicates that it is not significantly accepted by HR managers.

\section{DISCUSSION}

The study is focused on the very novel concept of outsourcing of HR activities in Indian corporate sector. By outsourcing of human resource functions a company can be in better position and can focus on its core activities. They can work effectively in competitive environment, combat strategies of competitors and can deal effectively with internal employees. Findings revealed that HR outsourcing is beneficial for an organization. The major finding of our study matches with (Kaliannan et al., 2016). They found that most of the organizations report that they are benefitted with HR outsourcing. It is the best method to reduce their regular burden and save their cost. It is helpful in increase the performance of organization. Findings also show that it brings innovation to their organization. HR outsourcing can help in strategic decisions. However, outsourcing is not devoid of limitations as the study also highlighted few challenges of being faced by HR managers. Problems in vendor selection, conflicts between internal and external employees, lack of knowledge regarding HR outsourcing, difficulty in coordination came up as the challenges of outsourcing. HR managers ought to be responsive about these vexing issues while using HR outsourcing. The results of the present study will be valuable for an organization to comprehend the HR outsourcing in a better way and to gain maximum out of this innovative practice. The study will also be beneficial for HR departments of various organizations to strategically choose between to outsource or not?

\section{LIMITATIONS AND FUTURE RESEARCH DIRECTIONS}

It is found that present study has been done on studying the perception of HR managers with regard to benefits and challenges of HR outsourcing. So, further study can be conducted on other dimensions and with increased sample size. Impact of HR outsourcing on the performance and productivity of the organization can also be studied in future.

\section{REFERENCES}

1) Adler, P. S. (2003). Making the HRM Outsourcing Decision. MIT Sloan Management Review, 45, 53-60.

2) Azhar, S. (2013).Human Resource Outsourcing. 1-15, retrieved from http://cgr.umt.edu.pk/ icobm2013/index.html on 18 Nov. 2013.

3) Buller P.F. and Mcevoy, G. M. (2012). Strategy Human Resource Management and performance: Sharpening Line of Sight. Human Resource Management Review, 22(1), 43-56.

4) Berber, N., and ślavic, A. (2016). Human Resource Outsourcing in European Compensation Management in the light of Carnet Research. ActaPolytechnicaHungarica. 13(3), 207-225.

5) Cassale, F. J. (1996). Introduction to Outsourcing. The outsourcing institute. Retrieved from http:// www.Outsourcing.Com/howandwhy/ top1 / main.html, 1-14.

6) Cook, M. F. (1999). Outsourcing human resources functions: Strategies for providing enhanced HR services at lower cost. American Academy Association, New York, NY

7) Cook, F. L., Shen, J. and Mcbride, A. (2005), Outsourcing as a competitive strategy? Human Resource Management, 44(4), 413-432.

8) Cronbach, L. (1951). Coefficient alpha and the internal structure of tests.Psychometrika.16(3), 297-334. 
9) Elmuti, D. (2003). The perceived impact of outsourcing on organizational performance. Mid-American journal of Business, 18(2).

10) Fapohunda, T. M. (2013). Towards Successful Outsourcing of Human Resource Functions. International Journal of Human Resource Studies, 3(3), 39-49.

11) Galanaki, E., and Papalexandries, N. (2007) Internationalization as a determining factor of HRM outsourcing, International Journal of Human Resource Management, 18(8), 1557-1567.

12) Gallagher, P. (2000), Human Resource Planning, Scitech Educational.

13) Gilley, M. and Rasheed, A. (2000). Making more by doing less: An analysis of outsourcing and its effect on firm performance, Journal of Management, 26 (4), 763-790.

14) Jirawuttinunt, S. (2015). The effect of HRM outsourcing on performance of multinational firms in Thailand. Journal of Business and Retail Management Research (JBRMR), 116-125.

15) King, W.R. (2007). The IS Organization of the Future: Impacts of Global Sourcing. Information Systems Management, 24(2), 121-128.

16) Kodwani, D. A. (2007). Human Resource Outsourcing: Issues and Challenges. The Journal of Nepalese Business Studies, IV (1), 38-46.

17) Laabs, J. C. (1997). Why HR is turning to outsourcing. Workforce On-Line Research Centre, retrieved from w w w . workforceon line.com / me m / policies_and_Procedures/2529.html on June 12, 2014.

18) Lau, K.H. and Zhang, J., (2006). Drivers and Obstacles of Outsourcing Practices in China. International Journal of Physical Distribution and Logistics Management, 36(10), 776 -792.

19) Lever, (1997). An analysis of managerial motivations behind outsourcing practices in
Human Resources. Human Resource Planning, 20(2), 37-47.

20) Mahmud, K., Billah, M. M., Chowdhury, M. R. S. (2012). Human Resource Outsourcing: A Study on Telecommunication Sector in Bangladesh. International Journal of Business and Management, 7(10), 74-84.

21) Outlay, C. and Ranganathan, C. (2005).Exploring the downside of IT outsourcing: Outsourcing tactics, layoffs and organizational outcomes. Americas Conference on information system ((AMCIS) -AMICS 2005Proceedings 20-27.

22) Pelham, D. (2002). Is it time to outsource HR? Training, 39(4).

23) Quinn, J. B., Doorley, T. L., Paqette, P. C. (1990). Technology in services: Rethinking strategic focus. Sloan Management Review, 31(2), 79-87.

24) Roberts, V. (2001).Managing strategic outsourcing in health care industry. Journal of Healthcare Management, 46(4), 239-249.

25) Seth, M. and Sethi, D. (2011). Human Resource Outsourcing: Analysis Based On Literature Review, International Journal of Innovation, Management and Technology, 2(2), 127-135.

26) Simmonds, D. and Gibson, R. (2008).A model for outsourcing HRD. Journal of European Industrial, 32(1), 4-18.

27) Smith, P. C., Vozoikis, G. Varaksina, L. (2006). Outsourcing Human Resource Management: A comparison of Russian and U.S. Practices, Journal of Labor Research, 27(3), 305-321.

28) Stasiulytė, E. (2011). Motives of human resource management outsourcing: a case study from Lithuania. Interdisciplinary Approach to Economics and Sociology, 4(1), 116-125.

29) Quinn, J. B., Doorley, T. L., Paqette, P. C. (1990). Technology in services: Rethinking strategic focus. Sloan Management Review, 31(2), 79-87. 